\title{
WEEDS-VEGETABLES AND FRUITS ACT AS POTENTIAL BIOMEDICINES AGAINST COVID-19: ENRICHED AGRICULTURE BIODIVERSITY SOCIO-ECONOMY SCIENCE TECHNOLOGY COMMUNICATION BY CONTROLLING PLANT DISEASES
}

\author{
Subhas Chandra Datta* \\ Headmaster\& Secretary, Eco-Club, Kanchannagar D.N.Das High School (HS), Kanchannagar, Burdwan-713102, West Bengal, India.
}

Received - September 28, 2020; Revision - October 25, 2020; Accepted - November 06, 2020

Available Online November 09, 2020

DOI: http://dx.doi.org/10.18006/2020.8(Spl-1-SARS-CoV-2).S139.S157

KEYWORDS
Weed-vegetables-fruits
Biomedicines-COVID-19
Enriched-agriculture
Socio-economy
Science-technology
Plant-diseases

Plant-diseases

\begin{abstract}
The past two decades have seen several viral-epidemics, causing great loss of human lives. The recent COVID-19 epidemics emerge as serious-global-threat to human civilization, public health, agriculture, travel, socioeconomic, education and even clinical research also. It has no specific therapeutics, and effective treatment options. Though the middle and upper classes are able to manage, but the low income households are really suffering. So Government of India wants to reorient the COVID-19 crisis by developing policy initiative. So it is focused on the consumption of nutritious as well as traditional medicinal weed vegetables and fruits, for preventive measures against human-diseases which are naturally infected with different pathogens caused diseases and significantly decreasing food production. Though pesticides are the most effective means of control, but they are costly and not environment friendly. So, it is emphasized on the multiple-intercropped weed vegetables fruits plants of the 4 plants species viz., amaranth, cucumber, cowpea, and okra plants, and determines the effects on pathogens infected diseases; Root Knot and Mosaic Virus. After harvesting, of these 4 plant species, amaranth and cucumber received maximum infection, forming the "Eco-Friendly-Highly-Economical-PotentialBiomedicines-Cover-Catch-Weed-Vegetable-Fruits-Crop-Plants", conserving "Biodiversity-ConservationsSustainable-Climate-Health-Development-Green-Socio-Economic-Implications-Agriculture”, though all are highly susceptible to pathogens and the farmers would be double benefited; by controlling diseases, and by marketing. In biomedicines, weed-vegetables fruits OR the plant-Mosaic-Virus has been developed as antigenic epitopes derived from the vaccine targets-COVID-19 infectious epidemic disease agents, and the chimeric virus particles, use in vaccine formulations or treatments, as one of the most-powerful
\end{abstract}

* Corresponding author

E-mail: dattasubhas@ rediffmail.com; subhaschandra.datta@gmail.com (Subhas Chandra Datta)

Peer review under responsibility of Journal of Experimental Biology and Agricultural Sciences.

Production and Hosting by Horizon Publisher India [HPI] (http://www.horizonpublisherindia.in/).

All rights reserved.
All the articles published by Journal of Experimental Biology and Agricultural Sciences are licensed under a Creative Commons Attribution-NonCommercial 4.0 International License Based on a work at www.jebas.org.

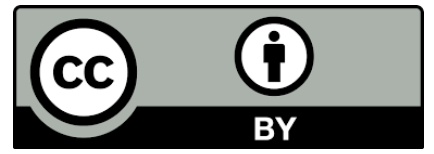


cost-effective emergency-healthcare-easily-available safe-edible prepare-able easy-applicable future-personalized-potential-biomedicines act as "Preventive-Measures and Safe-Alternative-toLive-Replicating-COVID-19-Vaccines", by increasing our natural-immune system, which is one of the milestone events amidst many important changes in the past decade that have necessitated formulation of a new-outlook and strategy for preventing-"Future-Pandemic-Pathogens-of-21stCentury-Advances-Research-Diagnosis-Treatment-Control-Enriching-Food-Security-BiodiversityAgriculture-Green-Socio-Economy-Medical-Science-and-Technology-Communication-ApplicationsInnovation-Issues", based on the theme "Vision 2040" that would help policy-makers.

\section{Introduction}

The past two decades have seen several viral epidemics, causing great loss of human lives, and the current 'human-challenge' pandemic coronavirus disease 2019 (COVID-19), caused by a novel coronavirus "sever acute respiratory syndrome coronavirus -2 (SARS-CoV-2), has shown unique global challenges to human civilization, our private and professional life and the social organization communities, health systems "the invisible patients", devastating social and economic consequences, truism and education (Guleria \& Srivastava, 2020; Cohen, 2020a; Filetti, 2020; Cal et al., 2020; Blumenthal et al., 2020; Madhusoodanan, 2020; Malik et al., 2020; Rodriguez-Morales et al., 2020). Reopening of the educational institutions could also threaten the surrounding community, and employees will not be permitted to teach or work (Madhusoodanan, 2020). So the scientists, have been an urgency to develop vaccines against coronavirus (Brouwer et al., 2020; Yatoo et al., 2020) or to find out the quickest and most efficient effective treatment pathway and prevention strategies, but remain careful regarding scientifically robust and ethically sound clinical research (Dhama et al., 2020a; Rabaan et al., 2020; Science Daily, 2020). The fifth endemic coronavirus, leaps from animals, forming humans health danger in the future due to very closely related animal-human virus, genetic resistance, divergence, structural and the future evolution, adaptation, and spread, prevails a long time as an asymptomatic patients, and the recent, pandemic situation is analogous to war, the delay of every week in the deployment of a vaccine to the seven billion humans on earth will cost thousands of lives, and WHO develops a blueprint for diagnostics, vaccines, and therapeutics against novel coronavirus (Buschman \& Skamene, 2019; Ciotti et al., 2020; Cohen, 2020a; Julka, 2020; Roujian et al., 2020; Science Daily, 2020; WHO, 2020f; Zhang \& Holmes, 2020). It has no targeted therapeutics, and effective treatment options, remain very limited. Though the middle and upper classes are able to manage, but the low income households, the marginalized in the cities, and groups like senior citizens, are really suffering (Karamchandani \& Rathi, 2020). So the Government of India, reorient in the wake of the COVID-19 crisis, a landmark policy-initiative has been flagged (GOI, 2020a; GOI, 2020b)

To overcome the pandemic situation, India emphasis on preventive measures by the cost-effective fresh weeds, vegetables and fruits (Plate 1); amaranth, cucumber, cowpea, and okra, qualify as an ideal food source for people of low income-food deficit countries, "Aid to Eating and Staying Healthy during COVID-19", to provide food and immunity, the entire plant is used to make medicine, resisting different diseases (Anonymous, 2015; Gemede et al., 2015; Fabbri \& Crosby 2016; Kumaraswamy, 2016; Agatemor et al., 2018; Datta, 2020d; Datta, 2020e; Datta, 2020f; Datta, 2020g; Govender, 2020; ISAAA Shares, 2020). But the global food security crisis in COVID-19 is significant problems (CBU, 2020a) and the production of vegetables and fruits; amaranth, cucumber, cowpea, and okra, are hampered adversely by the naturally occurring Root-Knot (RK) diseases caused by the nematodepathogens, Meloidogyne incognita (Kofoid and white, Chitwood, 1949), Amaranth Mosaic Virus (AMV) disease, Cucumber Mosaic
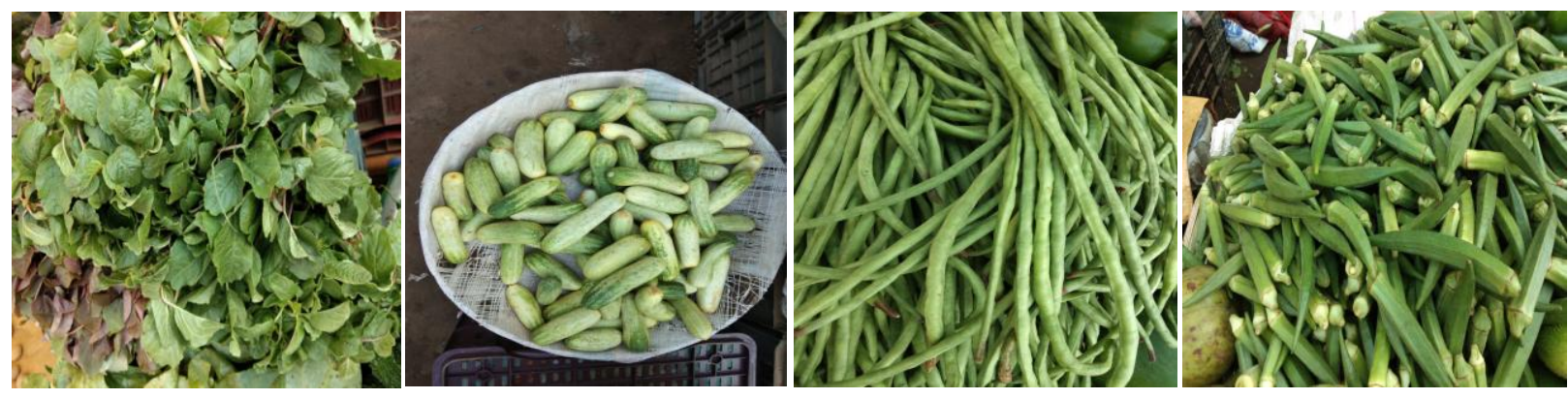

Plate 1 Amaranth, Cucumber, Cowpea and Okra weeds-vegetables and fruits

Journal of Experimental Biology and Agricultural Sciences http://www.jebas.org 
Virus (CMV) disease, Cowpea Mosaic Virus (CPMV) and Okra Yellow Vein Mosaic Virus (OYVMV) disease, caused by the virus-pathogens (Plate 2), which spreads by an insect vector, named-whitefly (Bemisia tabaci Gen). The use of chemicals is the most effective means of control, but they are expensive and not environment-friendly creating different health hazards (Datta,1999; Datta, 2005), and climatic changes impact on the global economy also (Valipour,2014; Valipour, 2015).

A number of phytomedicines or biomedicine or bio-agents or bionematicides only stand as a suitable and useful against different plants, animals and human diseases caused by pathogens, and recently also have been identified to possess potential against SARS-CoV-2 / COVID-19 (Datta et al., 1997; Datta et al., 1998; Datta, 1999; Datta et al., 2000; Datta \& Datta, 2000; Datta, 2005; Rahal et al., 2014; Dhama et al., 2015; Datta \& Datta, 2016; Dhama et al., 2018; Tiwari et al., 2018; Datta, 2020a; Arshad et al., 2020; Devanssh, 2020; Divya et al., 2020; Jahan \& Onay, 2020; Mani et al., 2020; Panyod et al., 2020; Staff Reporter, 2020). But it remains some problems in the rapid depletion of natural resources, biodiversity conservation, and not cost-effective (Datta, 1999; Datta, 2020f).

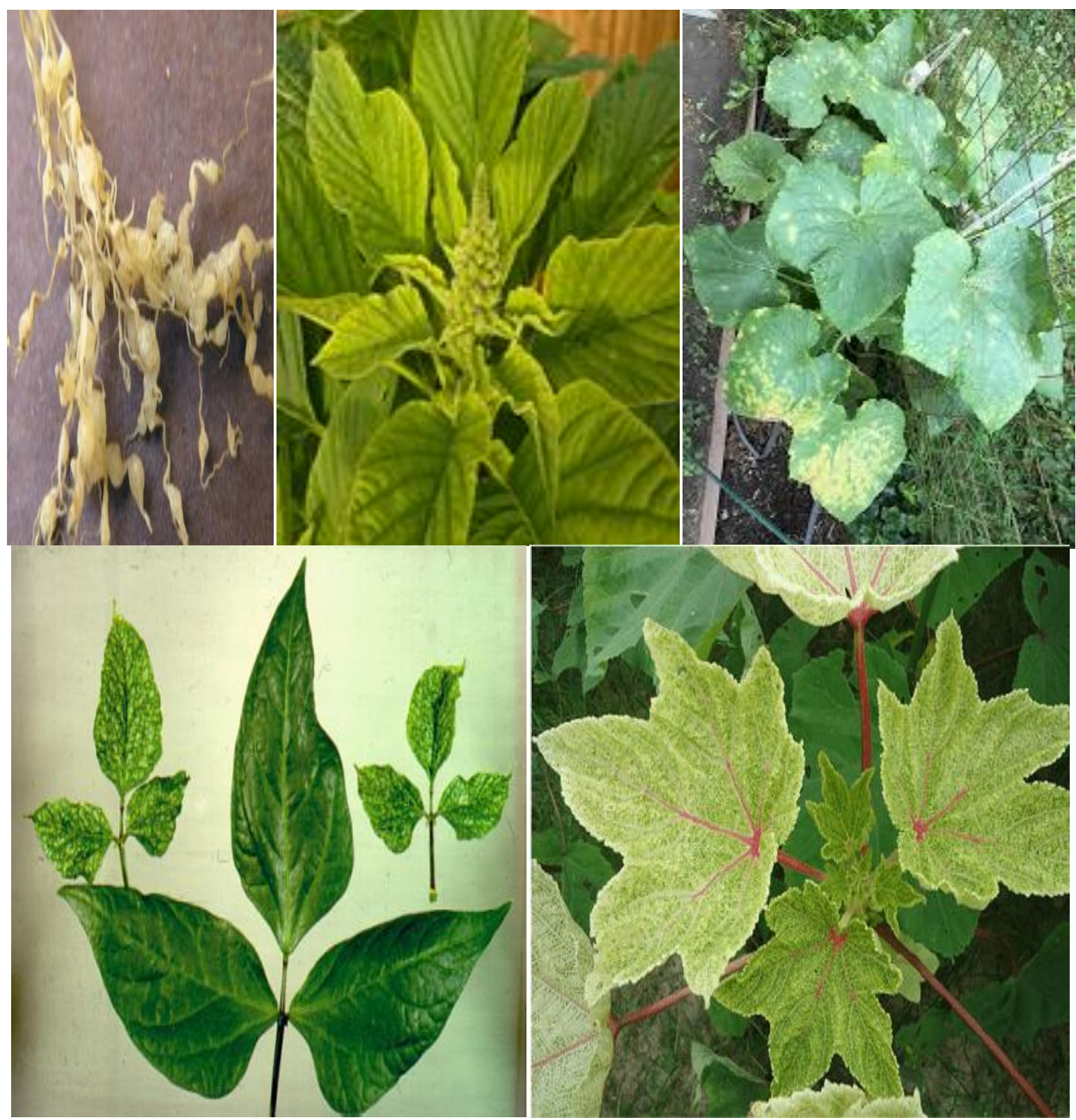

Plate 2 Amaranth, Cucumber, Cowpea and Okra Plants infected with Root-Knot and Mosaic Virus diseases

Journal of Experimental Biology and Agricultural Sciences http://www.jebas.org 
Then, it is thought that 'Homeopathy' may solve all the above mentioned problems (Datta, 2006; Datta \& Datta, 2012; Datta \& Datta, 2013; Datta, 2019b). But it has some cost. Only, intercropping would help in identifying the "Susceptible CatchVegetable-Fruits-Crop-Plants" for possible control of plant diseases caused by different pathogens and it is primarily observed (Datta et al, 2000; Datta, 2019a; Datta, 2020a; Datta, 2020b; Datta, 2020d; Datta, 2020e; Datta, 2020f; Datta, 2020g).

Now, the main aims and objectives of this article, are to find out the most suitable solution, a trial was planned in order to use of vegetables and fruits; amaranth, cucumber, cowpea, and okra, as a "Susceptible Catch Vegetable Fruit Crop Biomedicine Plants", multiple intercropped of 4-plants species, to determine the effects on pathogens-infected-diseases; Root-Knot (RK) and Mosaic Virus diseases, in a well-protected-garden. And to overcome the present epidemic COVID-19 disease, it is planned to publish as suggestions, for greater prevention against COVID-19, by boosting the human immune system.

\section{Materials and Methods}

\subsection{Location of the field trial}

The field experiment was administered at the well-protected garden of Kanchannagar D.N. Das High School (HS), Government of West Bengal, where the temperature was $28 \pm 5^{\circ} \mathrm{C}$, ratio was $75 \pm 5 \%$ and soil $\mathrm{pH} 5.8$, measuring $0.02 \mathrm{~h}$ land, infested with rootknot disease naturally (Datta et al.,1997; Datta, 2005; Datta, 2019a). Burdwan is extending from $22^{\circ} 56^{\prime}$ to $23^{\circ} 53^{\prime}$ North latitude and from $86^{\circ} 48^{\prime}$ to $88^{\circ} 25^{\prime}$ East longitudes. The experimental field has sandy soil, well-drained and slightly acidic in nature and therefore the average rainfall was 150 millimeters. All the information was counted for statistical analysis by the analysis of variance $(\mathrm{P} \geq 0.01)$.

\subsection{Preparation of the Sector Trial}

The experiment was conducted by the students of Kanchannagar D.N. Das High School (HS), Purba Bardhaman, Government of West Bengal. Soil was interchanged to stay the nematode population as uniform as possible with mixing manure (2:1 vol/vol). For uniform distribution, within the inoculated plots, soil and root samples were taken randomly to work out the extent and intensity of M. incognita -pathogen infestation by mixing @ 2,55,000 $\pm 25338 \mathrm{~J} 2$ / plot each ( $M$. incognita juveniles), and control plots were treated with predicament 5-times daily @ 15-days with sun-dry (Christie \& Perry,1951; Sukul,1987; Datta,1999; Datta et al., 2000; Datta, 2005; Datta \& Datta, 2016; Datta et al., 2016). These experimental fields were randomized within the infested field by employing a completely randomized block design. All the info was counted for statistical analysis by analysis of variance $(\mathrm{P} \geq 0.01)$.

\subsection{Plantation}

Aseptically germinated seeds of amaranth (Amaranthus viridis L. cv.CO-1), cucumber (Cucumis sativus L. cv local Slicing variety), cowpea (Vigna ungyculata L. cv.5269), and okra (Abelmoschus esculentus L. cv. Ankur-40) and were planted alternately with a niche of $25 \mathrm{~cm}$ within the control and infected inoculated plots. Since amaranth was a slow-growing plant, it had been planted 15 days before the other 3-plants. The plots were: uninoculated control and infected inoculated plots, replicated thrice (Datta et al., 2000; Datta et al., 2016; Datta, 2020d). The naturally infected Root-Knot and Yellow-Vein-Mosaic-Virus-diseases occurred at the 4-leaf stage of plants. All the info was counted for statistical analysis by analysis of variance $(\mathrm{P} \geq 0.01)$.

\subsection{Harvesting}

Sixty-five days after plantation of cucumber, cowpea, and okra, all the plants were uprooted and therefore the following parameters of growth and pathogens infection were recorded: average number of leaves /plant, the typical number of Yellow-Mosaic-Virus diseaseinfected leaves/plant (\%), the typical number of root galls/plant, the typical number of nematodes (Root-Knot) per $2 \mathrm{~g}$ of root and $200 \mathrm{~g}$ soil, average biomass ( $\mathrm{g}$ ) of fresh weight of shoot and root, and average folding of root and fruits- protein content. Three samples of root from each species of plants were taken randomly and therefore the total protein fraction in each sample was estimated (Christie \& Perry,1951; Lowry et al., 1951; Chatterjee \& Sukul, 1981; Sukul, 1987; Datta,1999; Datta,2005;). All the info was counted for statistical analysis by analysis of variance $(\mathrm{P} \geq 0.01)$.

\subsection{Recipe for Consumption}

The vegetables and fruits plants; amaranth, cucumber, cowpea, and okra, are tasty delicacy found in many dishes, making it quite versatile vegetable, and consumed during a sort of ways and may be utilized in salads, soups, stews and sauces, chopped, sliced, fresh or dried, fried or boiled (Kochlar,1986; Annor et al.,2014; Kumaraswamy, 2016; Agatemor et al., 2018; Govender, 2020).

\subsection{Processing Methods}

Different processing methods of vegetables and fruits plants; boiling, sprouting, steaming, frying, soaking, de-hulling, and grinding, are often combined to supply different meals (Annor et al., 2014). However, there's information available on the standard and dietary characteristics of fresh vegetables-fruits, which are occasionally utilized in folk diets in some southern European countries (Fabbri\& Crosby,2016). Cooking and sprouting of legumes greatly alters the properties and bioavailability of some nutrients, and a number of other metabolic enzymes, like proteinases, are activated during this process, which results in the 
discharge of amino acids and peptides to synthesize new proteins (Devi et al., 2015; Govender,2020).

2.6 Healthcare Science and Technology Communication Food Security Economy

The activity of scholars, researchers, regulators, teachers, staff, community, photographers, visitors, different scientist, academicians, clinicians, administrators, institutions, farmers, NGO named 'Burdwan Green Haunter and Students' Goal', and media personnel, -campaign or -aware or -make the news or -publication regarding the importance of "Vegetables and Fruits act as Potential Cost-Effective Personalized-Biomedicines Social-Vaccine against COVID-19: Improved Immunity Food-Security Green-Economy Science-and-Technology-Communication Applications and Nutritious foods-, Healthcare-, Defense response- and Immunityalso as Biodiversity Conservation- Issues" in several audiovisual media (TV channels), social media, web pages, newspapers, and journals, are recorded. it's a platform to market and discuss different new issues and developments by publishing case reports altogether aspects of Clinical Medicine for everywhere the world (Datta et al.,1997; Datta et al., 1998; Datta,1999; Datta \& Datta,2000; Datta et al., 2000; Datta, 2005; Datta, 2006; Datta \& Datta, 2012; Datta \& Datta, 2013; Datta \& Datta, 2016; Datta, 2016; Datta, 2019a; Datta, 2019b, Datta, 2020a; Datta, 2020b; Datta, 2020c; Datta, 2020d; Datta, 2020e; Datta, 2020f; Datta, 2020g).

\subsection{Future Suggestions in Research}

It will be achieved from typical analysis or justifications of literature review, research articles, specifies hypotheses, backgrounds, and problems. Emphasize the new and important aspects of the experimental findings and the conclusions. Then new hypotheses will arise and clearly label them as such trials for education and prevention are the ultimate keys to extending good health and nutrition globally (Datta, 2016; Datta,2019a; Datta, 2020a).

\section{Results}

Results mentioned in table1, shows that the susceptibility of vegetables and fruits plants infected with Root-Knot and Mosaic Virus diseases during a multiple intercropped field by analysis of variance $(P \geq 0.01)$. Here amaranth and cucumber received maximuminfection of Root-Knot and Mosaic Virus, and amaranth and cucumber, were more susceptible plant than cowpea and okra plants, and determines the results on pathogens-infected-diseases; RootKnot and Mosaic-Virus, in terms of the typical number of; root-gall number, nematode population in root, leaves /plant, Mosaic-Virusinfected leaves/plant (\%), biomass of shoot and root, length of shoot and root, average root and fruit protein content (\%), forming the "Eco-Friendly-Highly-Economical-Potential-Biomedicines-CoverCatch-Weed-Vegetable-Fruits-Crop-Plants". On the opposite, okra and cowpea act as a "Diseases-Resistant-BiomedicineVegetables"-crop against naturally pathogens-infected-diseases by analysis of variance $(\mathrm{P} \geq 0.01)$, though all the four plants were liable to root-knot nematodes and foliar diseases. While, M. incognita population increased significantly both within the soil likewise as in roots in 65 days. But okra showed very cheap intensity of nematode infection (Table 1).

\subsection{In Future Suggestions in Research}

The results fulfill the goal fof research suggestions as proposal because the consumption of the multiple-intercropped vegetablesfruits plants; amaranth, cucumber, cowpea, and okra plants, use as potential biomedicines, must justify future research.

\subsection{In Healthcare Medical Sciences and Technology Communication Food Security}

The students, researchers, teachers, staff, community, photographers, visitors, different scientist, administrators, institutions, farmers, NGOs, and media personnel campaign,

Table1 Susceptibility of vegetables and fruits plants infected with Root-Knot and Mosaic Virus diseases in a multiple intercropped field

\begin{tabular}{|c|c|c|c|c|c|c|c|c|c|c|c|}
\hline \multirow{3}{*}{$\begin{array}{c}\text { Plant } \\
\text { species }\end{array}$} & \multirow{3}{*}{$\frac{\text { Leaves }}{\text { / plant }}$} & \multicolumn{7}{|c|}{ Ratio: Control / Infected } & \multirow{3}{*}{$\begin{array}{l}\text { Root galls / } \\
\text { plant }\end{array}$} & \multicolumn{2}{|c|}{ Nematodes (populations) } \\
\hline & & $\begin{array}{l}\text { Mosaic Virus } \\
\text { infected }\end{array}$ & \multicolumn{2}{|c|}{ Average shoot } & \multicolumn{2}{|c|}{ Average root } & \multicolumn{2}{|c|}{$\begin{array}{c}\text { Average } \\
\text { protein }(\%)\end{array}$} & & & \\
\hline & & $\begin{array}{c}\text { leaves / plant } \\
(\%)\end{array}$ & $\begin{array}{l}\text { Length } \\
(\mathrm{cm})\end{array}$ & $\begin{array}{l}\text { Weight } \\
\text { (g) }\end{array}$ & $\begin{array}{l}\text { Length } \\
(\mathrm{cm})\end{array}$ & $\begin{array}{l}\text { Weight } \\
\text { (g) }\end{array}$ & Root & Fruits & & Soil (200g) & Root (2g) \\
\hline Amaranth & $0.97^{\mathrm{c}}$ & $0.95^{\mathrm{d}}$ & $1.58^{\mathrm{a}}$ & $1.93^{\mathrm{a}}$ & $1.83^{\mathrm{b}}$ & $0.25^{\mathrm{c}}$ & $0.53^{\mathrm{c}}$ & $1.06^{\mathrm{c}}$ & $4435.62 \pm 14.02^{\mathrm{a}}$ & $112.02 \pm 2.92^{\mathrm{a}}$ & $2276.74 \pm 12.22^{\mathrm{a}}$ \\
\hline Cucumber & $0.89^{\mathrm{c}}$ & $1.41^{\mathrm{c}}$ & $1.51^{\mathrm{a}}$ & $1.99^{\mathrm{a}}$ & $3.42^{\mathrm{a}}$ & $0.23^{\mathrm{c}}$ & $0.51^{\mathrm{c}}$ & $1.18^{\mathrm{b}}$ & $586.93 \pm 05.01^{\mathrm{b}}$ & $112.02 \pm 2.92^{\mathrm{a}}$ & $1586.97 \pm 04.29^{b}$ \\
\hline Cowpea & $1.06^{\mathrm{b}}$ & $1.72^{\mathrm{b}}$ & $1.38^{\mathrm{b}}$ & $1.29^{\mathrm{b}}$ & $1.28^{\mathrm{c}}$ & $0.58^{\mathrm{b}}$ & $0.80^{\mathrm{b}}$ & $1.04^{\mathrm{c}}$ & $98.27 \pm 09.03^{\mathrm{c}}$ & $112.02 \pm 2.92^{\mathrm{a}}$ & $478.96 \pm 02.82^{c}$ \\
\hline Okra & $1.10^{\mathrm{a}}$ & $1.91^{\mathrm{a}}$ & $1.07^{\mathrm{c}}$ & $1.12^{\mathrm{a}}$ & $1.13^{\mathrm{c}}$ & $0.99^{\mathrm{a}}$ & $0.93^{\mathrm{a}}$ & $1.51^{\mathrm{a}}$ & $21.04 \pm 10.12^{\mathrm{d}}$ & $112.02 \pm 2.92^{\mathrm{a}}$ & $28.93 \pm 09.03^{\mathrm{d}}$ \\
\hline
\end{tabular}

Value given are average of five replicates; mean \pm SE value followed by the different letter in same vertical column are significantly different according to Duncan's multiple range test $(\mathrm{P}=0.01)$ 
aware, discuss, arrange workshops and seminars, make news and publish as abstract regarding the importance of "COVID-19 CostEffective Social-Vaccine Develop from Potential VegetablesFruits-Biomedicines: Improving Immunity Healthcare Medical Sciences and Technology Communication Food-Security GreenEconomy Applications, and Nutritious foods-, Healthcare-, Defense response- and Immunity- yet as Biodiversity Conservation- Issues", in numerous national- and localaudiovisual media (TV channels), different social media, web pages, newspapers and different -national and -international Journals further as Congress Proceedings also.

\section{Discussions}

\subsection{In Unidirectional Common Thread Healthy Diet Prevention COVID-19}

The cost-effective fresh weed, vegetables and fruits; amaranth, cucumber, cowpea and okra, qualify as an ideal nutritious food source for people of low income-food deficit countries, and these are used to make medicine, -"Aid to Eating and Staying Healthy during COVID-19", to provide food for immunity (Annor et al., 2014; Devi et al., 2015; Pulipati et al.,2014; Gemede et al., 2015; Fabbri\& Crosby, 2016; Kumaraswamy, 2016; Agatemor et al., 2018; CABI, 2020; Datta, 2020d; Datta, 2020e; Datta, 2020f; Datta, 2020g; Govender, 2020; Guleria\& Srivastava,2020; ISAAA Shares, 2020).

\subsection{Advantages of Weed-Vegetables and Fruits as Biomedicines}

\subsubsection{Potential Catch Crop}

It is evident from the observation that amaranth, cucumber, cowpea and okra plants were highly susceptible to Root-Knot (RK) and Mosaic-Virus (MV). But, here amaranth and cucumber received maximum-infection of Root-Knot and Mosaic Virus, and were more susceptible plant than cowpea and okra plants, and determines the effects on pathogens infected diseases in comparison to inoculated naturally infected plots. Though, all the plants, are very good hosts of these Root Knot nematodes as well as foliar MV pathogens (Datta et al.,1997; Datta, 1999; Datta et al., 2000; Roossinck, 2001; Datta, 2005; Datta, 2006; Datta \& Datta, 2013; Anonymous, 2015; Datta \& Datta, 2016; Datta et al., 2016; Datta, 2016; Datta, 2019a; Datta, 2019b, Datta, 2020d). However, root-knot nematodes liked to feed on amaranth and cucumber rather than cowpea and okra when it had a choice, forming the "Eco-Friendly-Highly-Economical-Potential-Biomedicines-CoverCatch-Weed-Vegetable-Fruits-Crop-Plants". Here both the amaranth and cucumber root system colonizes and occupies the large area, it is likely that the plant-parasitic nematodes will preferably be found in its roots (Datta et al.,1997; Datta, 1999; Datta et al., 2000; Datta, 2005; Datta, 2006; Datta \& Datta, 2013;
Datta \& Datta, 2016; Datta et al., 2016; Datta, 2016; Datta, 2019a; Datta, 2019b, Datta, 2020d). In other words, amaranth and cucumber could serve as a good potential catch crop thereby reducing pathogens infection of other vegetables. On the other hand, okra and cowpea act as a "Diseases-Resistant-BiomedicineWeed-Vegetables-Fruits-Crops"- against naturally pathogensinfected-diseases.

\subsubsection{Double Benefits}

In multiple-intercropping, land equivalent ratio, benefit-cost ratio, and monetary advantage index are used to assess the productivity and its economic benefits. The farmers would be benefited double; by controlling root-knot diseases, and by buying and selling the amaranth, cucumber, cowpea and okra (Datta et al.,1997; Datta, 1999; Datta et al., 2000; Roossinck, 2001; Datta, 2005; Datta, 2006; Datta \& Datta, 2013; Anonymous, 2015; Datta \& Datta, 2016; Datta et al., 2016; Datta, 2016; Datta, 2019a; Datta, 2019b, Datta, 2020d).

\subsubsection{High Tolerance to Environmental Stresses}

The influence of environmental factors on vegetables and fruits to temperature, solution $\mathrm{pH}$, moisture stress, depth of emergence, hexavalent chromium-Cr (VI) stress, drought, nickel and use dual crop are high (Thomas et al.,2009; Bashri et al., 2016; Massawe et al., 2016; Datta, 2016; Datta, 2019a; Datta, 2020d).

\subsubsection{Food Security in Agriculture for Climate Change and Chemicals' Usage}

Plants growth directly increases with photosynthesis and stomatal activity, conserves solar energy in the glucose, and significantly reduces $\mathrm{CO}_{2}$ in the climate. So we can say that both plants might have induced synthesis of many new proteins which increase photosynthesis have stimulated increased photosynthesis rate, stomata-activity, and water retention capacity plants by inducing defense response (Datta, 2005; Datta, 2006; Datta \& Datta, 2013; Datta \& Datta, 2016; Datta et al., 2016; Datta, 2016; Datta, 2019a; Datta, 2019b, Datta, 2020d). These results may suggest that plant diseases might be effectively controlled by the amaranth and cucumber plants as a 'Potential Cover Vegetables CatchCrops'. It is a new and more efficient solution, technologies, products and it has to fulfill its food and nutrition requirement (Datta,2019a; Datta, 2020c; Datta, 2020d), which indirectly influence climate change and resource productive economies enriching quality of midday meal as well as the agricultural sector in food security (Datta, 2005; Datta, 2006; Datta \& Datta, 2013; Datta \& Datta, 2016; Datta et al., 2016; Datta, 2016; Datta, 2019a; Datta, 2019b, Datta, 2020d). The fertilizers-pesticides, plus improvements within the crop input use efficiency could minimize greenhouse gas emissions while protecting the environment. Sustainable 
agriculture holds promise for humankind and therefore the plane Earth, and it will be successful if all developed and developing nations stand together to hunt 'our common future' to provide more food while generating less environmental pressure (Shah \& $\mathrm{Wu}, 2019)$.

\subsubsection{Consumption of Weeds-Vegetables and Fruits with Genetic Improvements for Prevention $21^{\text {st }}$ Century Epidemiological Diseases}

Amaranth, cucumber, cowpea and okra are the older widely cultivated, for both medicinal and culinary oligo-purpose, the costeffective fresh vegetables-fruits, qualify as an ideal safe food for people of low income countries and also has economic viability, and it is easily available in all regions, low priced, seed, oil, and leaf are used as food, -“Aid to Eating and Staying Healthy during COVID-19", to provide nutritious food and immunity, fruits or entire plants are used to make modern medicine, resisting different diseases; analgesic, diuretic, antifungal,vermifuge, antiulcer, laxative, antiviral, asthma, ulcers, diarrhea, swelling of the mouth or throat, and high cholesterol and hypertension, hepatoprotective and antioxidant activities, and it is developed a blueprint for diagnostics, vaccines, and therapeutics against novel coronavirus (Ware,2019; Datta,2020c; Datta,2020d; Datta,2020e; Datta,2020h; Govender,2020; WHO,2020f), forming the 'Nature's Gift to the poor human disease-free healthy life' multipurpose crop (Sindhu \&Puri,2016; Kuete et al.,2017; Jayathilake et al., 2018; WHO,2020a; WHO,2020b), consumed in a variety of ways, fruits rich in vitamins, calcium, folic acid, carbohydrates, phosphorus, magnesium and potassium, iodine, and other mineral matters, and a good source of superior nutritional quality -oil and -protein, unsaturated fatty acids such as linoleic acid, and makes them easier to digest, and have several active constituents like tannins, resins, reducing sugars and amino acids. The methanolic leaves extract was reported for the presence of rutin and quercetin. It also possess spinosterol (24-ethyl-22-dehydrolathosterol) as a major component along with 24-methyllathosterol 24- ethyllathosterol, 24-methyl22- dehydrolathosterol, 24-ethyl cholesterol and 24-ethyl-22dehydrocholesterol as minor components in sterol fraction. The roots of A. viridis possess a steroidal component, amasterol (24methylene-20-hydroxycholesta- 5,7-dien-3 $\beta$-ol). Amaranth is also known for several potential pharmacological properties-health beneficial effects on human diseases, like cardiovascular disease, type 2 diabetes, kidney diseases, skin infection, digestive diseases, some cancers, antibacterial, antioxidant, nootropic, eye, body immunity, blood pressure, obesity, asthma, constipation, cancer, heart disease, obesity, osteoporosis, gastrointestinal health, sexual health, and neurological disorders, etc., (Annor et al.,2014; Anonymous,2015; Sindhu \&Puri,2016; Agatemor et al., 2018; Gondwe et al., 2019; Datta, 2020c; Datta, 2020d; Datta,2020g; Datta, 2020h). Among the diverse wild gene pool of weeds, vegetables and fruits holds the resistant source of gene for many biotic stresses, diseases and pests infestation, and resistant gene transfer, and also on germplasm (Pulipati et al., 2014; Boukar et al, 2019; Datta, 2020c; Datta, 2020d; Datta,2020g; Datta, 2020h).

\subsubsection{Defense Resistance and Soil Enrichments with Economic Benefits}

The positive effects of the expansion of both okra and cowpea plans is also accountable for defense resistance against other plant pathogens (Datta, 2005; Datta, 2006; Datta \& Datta, 2013; Datta \& Datta, 2016; Datta et al., 2016; Datta, 2016; Datta, 2019a; Datta, 2019b, Datta, 2020d). It's been reported that cowpea root-nodules increase soil nitrogen by biological organic process and therefore the amounts of $\mathrm{N}$ transferred to associated non-leguminous cropsokra determines the extent of advantages. In intercropping, land equivalent ratio, benefit-cost ratio, and monetary advantage index are wont to assess the productivity and its economic benefits (Massawe et al., 2016; Olowolaju \& Okunlola, 2017).

\subsubsection{Stability and Persistence of Coronavirus on Vegetables- Fruits and Food Items}

There is no evidence of food borne transmission of COVID-19 to date that corona viruses being transmitted via food or food packaging, and it cannot multiply in food; they need an animal or human host to multiply, and did not expect that certain foods needed to be withdrawn (CDC, 2020a; CDC, 2020b; CDC, 2020c; FDA, 2020b; FSS, 2020; WHO, 2020h; WHO-FAO, 2020). Recently, many incidents highlighted frozen foods as carriers for the long-range transport of coronavirus, and low temperatures could dramatically prolong the persistence, frozen and refrigerated foods, contamination risk, fish, meat, poultry, and swine skin, during 14-21 days or more. The contaminated cold-storage foods may present a systematic risk for SARS-CoV-2 transmission between countries and regions (Casanova et al., 2010; CGTN 2020; Han et al., 2020; SMHC, 2020).

\subsubsection{Food Safety and Prevention strategies to Transmission Coronavirus}

It is reported that one cough can produce up to three thousand droplets, and therefore the coronavirus can remain active and possibly infectious for 3 hours in airborne droplets, which might also land on objects and surfaces around the vegetable moreover as a person, and people infected by touching these objects or surfaces. Coronavirus survive on different surfaces; it lasted up to four hours on copper alloys, it can survive on plastic, stainless-steel and countertops for up to 3 days (72 hours), the longest of all the materials, and is additionally detectable on cardboard for up to 24 hours, and it's also a decent indicator for other porous material like cardboard, like fabric and paper (Hammett, 2020). In the context of 
this situation, biosafety and biosecurity measures that focus on 'One Health' aspects of the disease outbreaks and so the COVID-19 spread are of great importance to restrain this pathogen along with these efforts, standard precaution and control measures should even be taken at the private and community level to prevent the spreading of any contagion diseases, including COVID-19, which specialize in the importance of biosafety, biosecurity, 'One Health' approach, which concentrate on recent developments and also the ways forward to forestall and control COVID-19 during a useful way (Ahmad et al., 2020; Bonilla-Aldana et al., 2020; Tiwari et al., 2020).

The effective food safety management systems are important for preventing infection-transmission COVID-19 via food and survival on food packaging materials. Cleaning, sanitation, good hygienic practices, and active packaging are needed from farm to fork (Dhama et al., 2020a; FAO \& WHO, 2020; Olaimat et al., 2020; Shariatifar \& Molaee-Aghaee, 2019; WHO, 2020i; WHO, 2020j; Unhale et al., 2020). Though, in China, supported their food health and risk perceptions of healthy and risky food, the respondents' general attitudes are positive toward organic food but relatively negative toward game meat. However, the likelihood of its impact on older generations' future changes in diets is smaller, which means that older generations' food beliefs are more stable (Xie et al., 2020; Zhang et al., 2020). So, the coronaviruses can already be inactivated at relatively low temperatures (Abraham et al., 2020; Hesslin et al., 2020). Traceability in food manufacturing can range from in-house traceability to whole or consumer, merchandise. Well-thought-out traceability systems are fundamental to achieving optimal benefits from internal control, production control, and for fulfilling consumer demands etc. and traceability strategy in food industries (Moe, 1998; Olsen \& Borit, 2013). Consuming unpackaged or uncovered foods, consumption of boiled or canned foods processed at high temperatures should be done, and nanoencapsulated materials are effective in protecting weeds-vegetables and fruits, and packaging from SARS-CoV-2 contamination (Ceyla et al., 2020). FDA (2020a) helps by supplying of sterilizers, disinfectant devices, and air purifiers. Sterilizers to be utilized; in health care to render medical devices sterile (i.e., free from viable microorganisms), ranging from small table-top sterilizers to large sterilizers intended for large loads, and modality by steam, ethylene oxide, vaporized peroxide, etc. or by bacterial spores, include chemical/physical disinfectant devices, and ultraviolet (UV) disinfectant devices, which are devices that use UVA or UVC light to provide a germicidal effect. Air purifying devices are intended for medical purposes to kill pathogens/microorganisms within the air by exposure to UV radiation or remove them through filtration (FDA, 2020a).

In general, coronavirus will be inactivated within a second by disinfecting surfaces with products containing $62-71 \%$ alcohol. Key surfaces to disinfect reception regularly are: phone, computers, keyboards, iPads, kitchen tops, shared utensils, taps, and also the flush handles within the bathroom, light switches, door handles, and bedside tables. we will also minimize spread by wearing (surgical) gloves, wearing medical masks when shopping (https://bit.ly/3bQwExL), staying at home, self-isolating from anyone in your household who is displaying symptoms, and avoiding populated places when exercising/getting fresh air, and decontamination of surgical face masks and $\mathrm{N} 95$ respirators by dry heat pasteurization for one hour at $70^{\circ} \mathrm{C}$ (Hammett, 2020; Xiang et al., 2020).

\subsection{Development of Ideas as Potential Biomedicine against COVID-19}

\subsubsection{From Genetic Similarity}

We're not completely human, the genetic material inside our cells; 100 forty-five genes from animals, and in 'Genome Biology', the numerous genes that gave the impression to are transferred from bacteria, archaea, fungi, other microorganisms, and plants to animals. In the case of humans, they found hundred forty-five genes have jumped from simpler organisms (Williams, 2015) and underpinning all organisms (Appels et al., 2015). Approximately, fraction of the human genome of virus-DNA (Science Daily, 2016), shows the inter-individual variation (On Biology, 2019), "The Human Genome Is full of Viruses and our body requires viruses, but viruses don't always require a body" (Callif, 2020).

\subsubsection{From Genetic and Immune Resistance Mechanisms}

It is reported, "Genetic Resistance to Coronavirus Infection- A Review", three host resistance mechanisms: genetic control at the extent of the, -cellular receptors, -macrophage and -acquired immunity (Buschman \& Skamene,2019). SARS-CoV-2 is that the etiological agent to blamefor the pandemic COVID-19 outbreak and therefore the main protease (Mpro) of SARS-CoV2 could be a key enzyme that plays a very important role (Zhang et al., 2020). When the figure is attacked by germs, the system kicks into gear to repulse the assault (The Gene, 2020).

\subsubsection{From Traditional Medicine}

During the initial stages (December 2019) of the outbreak of COVID-19 in Wuhan city, Hubei province, China, Traditional Chinese Medicine (Yang et al., 2020) was considered to be the source of virus or wake of the coronavirus pandemic (Gorski, 2020), as it contains products from wildlife; like 'Tan Re Qing' from bear bile powder (Fobar, 2020), scales of pangolins, and tiger (Standaert, 2020; Vyawahare, 2020), bovine pill, gallstone of cattle, buffalo horn, jasmine and pearl etc., (Wee, 2020).But, in the evolution, the $70 \%-80 \%$ population is primarily dependent on traditional medicines and the innate response of the patient's 
immune system, highlighting anti-microbial peptides as the host's own defense molecules, and it could be used as potential therapeutic agents. The World Health Organization, Africa, also welcomes innovations around the world for potential treatments for COVID-19, and develops vaccine by using 'Plant-based Technology' (CBU, 2020b; Gómez et al., 2019; IUCN,1993; WHO, 2020b; Yatoo et al., 2020).

\subsubsection{From Human Immunomics Initiative}

Human Immunomics Initiative (HII) aims, how the human immune system fights disease with advances in computing and artificial intelligence, genomics, systems biology, and bioinformatics (Sweeney, 2020), following the guideline of WHO entitled "Vaccine-preventable diseases and vaccines" (WHO, 2020c), and the long-stay stress in emergencies (Bougrine et al., 2019), with harmonized clinical trials, are aimed to accelerate licensure and distribution by the public-private partnership and platform (Corey et al., 2020), due to more humid climates and summer weather will not substantially limit pandemic growth (Baker et al.,2020).

\subsubsection{From Nature of Binding}

The coronavirus, enters human cells by binding of its viral spike protein to the membrane-bound form of them aminopeptidase angiotensin-converting enzyme 2(ACE2) (Buschman \& Skamene, 2019; Roujian et al., 2020), protease inhibitors, and angiotensinreceptor, thus increasing the availability of target molecules for SARS-CoV-2 (Hoffmann et al., 2020; Soler et al., 2008; John et al., 2020). The T cells-immune warriors help us fight, because they were previously infected with other coronaviruses (Leslie, 2020), by 'Antibody Testing for COVID-19' by which designer antibodies could battle (Abbasi,2020; Cohen,2020c).

\subsubsection{From Antigenic Epitopes}

It is reported that deep serological profiling of COVID-19 patients and pre-COVID-19 era controls using VirScan revealed over 800 epitopes within the SARS-CoV-2 proteome, including 10 epitopes likely recognized by neutralizing antibodies for improving diagnostics, therapeutics, and vaccines (Shrock et al., 2020), and also the antigenic epitopes could constitute an economical and safe alternative to virus (Brennan et al., 2001).

\subsubsection{From Viral Nano-Biotechnology}

It is an emerging and interesting field, and plant virus-based nanoparticles are explored for several years either to precise subunit vaccines or as epitope presentation systems, and are developed for imaging, drug delivery, and therapeutic applications (Hema et al.,2019).

\subsubsection{From Coronavirus Updated Dashboard}

Scientists say that novel coronavirus forming a world crisis (Nicks et al., 2020). So, it's to wish

'Modeling of Coronavirus Infection' (Beverly,2020), 'WHOTimeline and Dashboard Updated' (WHO,2020c; WHO, 2020d; WHO, 2020e) and by using computing (AI) software (Robert, 2020), and therefore the global collaboration to accelerate the event, production and equitable access to new COVID-19 diagnostics, therapeutics, and vaccines (WHO, 2020a).

\subsection{Emergency Most Applicable Suggestions-Potential Global- COVID-19-Vaccine}

Plant-based vaccines offer several advantages over the standard systems like cautions and opportunities for botanicals in COVID-19 patients (Dhama et al., 2020b; Firenzuoli et al., 2020), simple production, storage, higher yields, stability and safety, and advantages in comparisons, prospects, and challenges or constraints within the production of plant-based vaccines and antibodies (Dhama et al., 2013; Dhama et al., 2020b; Parvathy, 2020). Now, the results and discussion fulfill the goal for the research suggestions.

\subsubsection{Idea-I}

In biomedicines, the Mosaic Virus of weeds-vegetables-fruits plants; amaranth, cucumber, cowpea, and okra plants Mosaic Virus, could also be utilized in vaccine formulations to control immune function against coronavirus, which has been developed as antigenic-epitopes (Shrock et al., 2020) derived from the vaccine targets COVID-19 infectious disease agents, and therefore the chimeric virus particles (CVPs) could represent an economical and safe alternative to measure replicating coronavirus vaccines (Brennan et al.,2001). And it's going to be effective by the humoral and cellular immune responses generated by these CVPs following both parenteral and mucosal delivery and highlight the potential of CVPs to elicit protective immunity from COVID-19 infection (Hema et al.,2019; Kuete et al., 2017; Datta, 2020b; Datta, 2020d; Datta, 2020c; Datta, 2020f; Parvathy, 2020). These plant virus-based nanoparticles are attracting the eye of researchers and clinicians for emerging, drug delivery, and therapeutic applications (Hema et al., 2019). Here, vaccination or treatments, is that the use of remedies against diseases either earlier in a pestilence or given routinely to forestall diseases. When the latter is employed it involves mostly the users similar to any conventional vaccination which administers the antigen in an inactive state to achieve immunity towards the disease and is given before the onset of disease or disease symptoms in a private as a prevention instead of cure (Rajput, 2012). It's obligatory that information on ClinicalTrials.gov, a resource provided by the U.S. National Library of drugs (NLM), to the National Institutes of Health 
(NIH) or other agencies of the U.S. central, is provided by study sponsors and investigators, and thatthey are to blame for ensuring that the studies follow all applicable laws and regulations $(\mathrm{NIH}$, 2017; Kaiser, 2020; Sweeney,2020). It's also studied the costeffectiveness of emergency care interventions, in low and middleincome countries like India (Brennan et al., 2001; Bio Spectrum News, 2020; Werner et al., 2020). But it'll not only be cost-effective but also easily available and prepare able, higher yields, stability and safety still as and safe alternatives to measure replicating COVID-19 vaccines (Bio Spectrum News,2020; Parvathy,2020; Robert,2020; Werner et al., 2020; WHO, 2020b; WHO, 2020c; WHO, 2020d; WHO, 2020e; WHO, 2020g).

\subsubsection{Idea-II}

The combined weeds-vegetables-fruits; amaranth, cucumber, cowpea, and okra (fresh or cooked) is also consumed as biomedicines@150g total (one and half cup) $(150 \mathrm{~g}=25 \mathrm{~g}$ amaranth $+50 \mathrm{~g}$ cucumber $+25 \mathrm{~g}$ cowpea $+25 \mathrm{~g}$ okra) twice daily (during taking meal) for aminimum of 6-weeks, against present coronavirus infections 45 -days before the symptom onset OR illness onset (as a vaccine) OR onset of symptoms (if possible) -associated COVID-19 infections are reported (treatments) (Bio Spectrum News, 2020; Datta, 2020b; Datta, 2020d; Datta, 2020e; Datta, 2020f; Datta, 2020h). The edible biomedicine-weed amaranth or okra may additionally be directly personal-used for "Clinical Trial or as a possible Global-Vaccine" after getting permission from the WHO, Clinical Trials.gov., U.S., NLM, and NIH (NIH, 2017; Kaiser, 2020; Sweeney, 2020). The combined weeds-vegetables-fruits, are the most; cost-effective, easily-available, safe-edible, and easily-prepare able likewise as and safe alternative to measure replicating COVID-19 vaccines (Rajput, 2012; Bio Spectrum News, 2020; Datta, 2020a; Datta, 2020b; Datta, 2020c; Datta, 2020d; Datta, 2020e; Datta, 2020f; Datta, 2020g; Datta, 2020h; Parvathy, 2020; Robert, 2020; Staff Reporter,2020; Werner et al.,2020; WHO, 2020b; WHO, 2020c; WHO, 2020d; WHO, 2020e; WHO, 2020g).

\subsubsection{Suggestions for Emergency Applications of Global- COVID-19-Vaccine}

\subsubsection{For Body's Defenses against Coronavirus Pathogens}

Eating weeds-vegetables-fruits based healthy diet with viosterol is extremely important during the COVID-19 pandemic because affect our body's ability to stop, fight and get over coronavirus infections by improving supporting immune systems which is reported within the 'Genome Biology and Evolution', these genetic changes may have sharpened the body's defenses against the pathogens (Datta, 2020a: Datta, 2020b; Datta, 2020c; Datta, 2020d; Datta, 2020e; Datta, 2020f; Datta, 2020g; Datta, 2020h; Lanham-New et al., 2020; NDTV FOOD, 2020; Parvathy, 2020; Ul et al., 2020).
4.4.3.2 For Weeds-Vegetables-Fruits Based Vaccines Offer Several Advantages

Some conventional vaccines though effective, have high production costs, involve tedious purification processes, and have biosafety issues, requiring time-consuming biosafety tests for commercial production. But plant-based vaccines and antibodies offer several advantages, like simple production, storage, higher yields, stability, and safety (Aoust et al., 2010; Bougrine et al., 2019; Capell et al., 2020; Drug Target Review, 2020; Filetti,2020; Kaiser, 2020; NIH, 2017; Mani et al., 2020; Parvathy, 2020; WHO, 2020a; WHO, 2020b; WHO, 2020c; WHO, 2020d; WHO, 2020e; WHO, 2020g).

\subsubsection{Tobe Used as Potential Personalized Vaccines}

There is a large international effort underway to develop diagnostic reagents, vaccines, and antiviral drugs in a very bid to cut down the spread of the disease and save lives, with a rapid supply of vaccines and antiviral drugs for the emergency manufacturing and application against COVID-19 (Capell et al., 2020; Werner et al., 2020), by inducing a potent immune reaction through both humoral and cellular components of the system (Aoust et al., 2010; Cohen, 2020a; Cohen, 2020b; Cohen, 2020c; Raw, 2020; WHO,2020a).

\subsubsection{For Cost-Effective Potential Global-Personalized-Vaccine}

The weeds-vegetables-fruits should be used as a potential emergency-care cost-effective personalized-biomedicine 'Vaccine or Social-Vaccine for all' because it resists and change unhealthy pandemic social and economic structures and useful metaphor for health promotion (Baumi et al., 2009; Aoust et al., 2010; Raw, 2020; Werner et al., 2020; WHO, 2020a), because it sharpened our immune system (Gibbons,2020), and the SARS-CoV-2 genome can provide useful information, on how drugs targeting other coronaviruses may improve outcomes for COVID-19 patients (Back, 2020). And the World Health Organization and other international organizations have set up a system to accelerate and equitably distribute vaccines, "the COVID-19 Vaccines Global Access (COVAX) Facility" (Blumenthal et al., 2020; Editorials, 2020; Filetti, 2020; Kupferschmidt, 2020; Martin, 2020), for preventing any controversy, with the "Biosimulation- can help to achieve the COVID-19 vaccine development" by avoid the dangerous rush for vaccines (Black, 2020).

\section{Future Approach in Research}

It will be achieved from typical analysis or justifications of literature review, which are the ultimate keys to extending good health and nutrition globally (ISAAA Shares, 2020; WHO, 2015; WHO, 2020c). In the future, combination of 'Weeds-Vegetables-Fruits' may not only be 'Potential Economical Crop' against various pathogens in agriculture, but also it is one of the milestone events 
amidst many important changes in the past decade that have necessitated formulation of a new-outlook-and-strategy for preventing-"Future Pandemic Pathogens of $21^{\text {st }}$ Century Advances Research Diagnosis Treatment Control Enriching Food Security Biodiversity Agriculture Green Socio-Economy Medical Science and Technology Communication Applications Innovation Issues", based on the theme "Vision 2040" that would help policy-makers to develop the "Potential Cost-Effective Green-Economical Emergency Potential Global-Vaccine specially for poor or Social-Vaccine Biomedicine against COVID-19 with Safe and Elicits Significant Immune Responses", and it resists and change unhealthy pandemic social and economic structures with the help of NGO, which may be 'Future Social Vaccine' (Baumi et al., 2009; Black,2020; Datta, 2020a; Datta, 2020b; Datta, 2020c; Datta, 2020d; Datta, 2020e; Datta, 2020h; Kupferschmidt, 2020; Martin, 2020; Thorp, 2020).

\section{Conclusions}

The combination of 'Weeds-Vegetables-Fruits' may not only be 'Potential Economical Crop' against various pathogens in agriculture, but also it may be forming the "Eco-Friendly HighlyEconomical Potential Biomedicines Cover Catch Vegetable-Fruits Crop-Plants", conserving "Biodiversity-Conservations-SustainableClimate-Health-Development-Green-Socio-Economic-Implications-

Agriculture", and the farmers would be benefited-double; by controlling-diseases, and by buying-selling. In biomedicines, vegetables-fruits or the plant-Mosaic-Virus has been developed as antigenic-epitopes derived from the vaccine-targets-COVID-19 infectious-epidemic-disease-agents, and the chimeric-virusparticles, use in vaccine-formulations or treatments, as one of the most-powerful cost-effective emergency healthcare easilyavailable safe-edible prepare-able easy-applicable futurepersonalized-potential-biomedicines act as "Preventive Measures and Safe Alternative to Live Replicating COVID-19 Vaccines", by increasing our immune system, which is one of the milestone events amidst many important changes in the past decade that have necessitated formulation of a new-outlook and strategy for preventing-"Future Pandemic Pathogens of 21st Century AdvancesResearch Diagnosis Treatment Control Enriching Food Security Biodiversity Agriculture Green Socio-Economy Medical-Science and Technology-Communication-Applications-Innovation-Issues", based on the theme "Vision 2040" that would help policy-makers.

\section{Conflicts of Interest}

The authors declare no conflict of interest. The idea was conceived by Datta SC and his higher secondary students and written by the author itself.

\section{Acknowledgments}

I thank World Vision of India, Burdwan for making a wellprotected nutritious garden and I am thankful to the eminent educationist Sri Tapaprakash Bhattacharya for inspiration and guidance. I express my deep gratitude to Mr. Rakesh Khan, Secretary and Mr. Subhendu Bose, President with all Young Green-Members of the "International NGO named Burdwan Green Haunter and Students' Goal" for arranging several awareness programmed on COVID-19 with "Health Care, Biomedicines, Nutritious Food, Vaccination, Agriculture, Biodiversity Conservation and Enriching Science and Technology Communication Economy Application Issues". Last but not the least; I am thankful to the eminent Senior Consultant Physician \& Cardiologist Dr. TusharKantiBatabyal, M.B.B.S., M.D., ExClinical Tutor of the Burdwan Medical College \& Hospital, for inspiration and guidance.

\section{Reference}

Abbasi J (2020) The Promise and Peril of Antibody Testing for COVID-19. Medical News \& Perspectives 323(19):1881-1883. doi:10.1001/jama.2020.6170.

Arshad MS, Khan U, Sadiq A, Khalid W, Hussain M, Yasmeen A, Rehana H (2020) Coronavirus disease (COVID-19) and immunity booster green foods: A mini review. Food Science \& Nutrition 8(8): 3971-3976.

Abraham JP, Plourde BD, Cheng L. (2020) Using heat to kill SARS-CoV-2. Reviews in Medical Virology 30(5):e2115.

Agatemor UMM, Nwodo OFC, Anosike CA (2018) Phytochemical and proximate composition of cucumber (Cucumissativus) fruit from Nsukka, Nigeria. African Journal of Biotechnology 17(38): 1215-1219. doi:10.5897/AJB2018.16410.

Ahmad T, Haroon, Dhama K, Sharun K, Khan FM, Ahmed I, Tiwari R, Musa TH, Khan M, Bonilla-Aldana DK, J RodriguezMorales A, Hui J (2020) Biosafety and biosecurity approaches to restrain/contain and counter SARS-CoV-2/COVID-19 pandemic: a rapid-review. Turkish Journal of Biology 44(3):132-145. doi: 10.3906/biy-2005-63.

Annor GA, Zhen MA, Boye JI (2014) Crops- legumes, in Food Processing:Principles and Applications, Vol. 2, ed. by Clark S, Jung S and Lamsal B, John Wiley and Sons, Inc., Chichester, West Sussex, UK, Pg No: 305.

Anonymous (2015) Indian Horticulture Database.National Horticulture Board, Ministry of Agriculture, Government of India, Gurgaon.

Aoust MAD, Couture MMJ, Charland N, Trepanier S, Landry N, Ors F, Vezina LP (2010) The production of hemagglutinin-based virus-like particles in plants: a rapid, efficient and safe response to pandemic influenza. Plant Biotechnology Journal 8: 607-619. doi:10.1111/j.1467-7652.2009.00496.x. 
Appels R, Nystrom J, Webster H, Keeble-Gagnere G (2015) Discoveries and advances in plant and animal genomics. Functional \& Integrative Genomics 15: 121-129. doi:10.1007/s10142-015-0434-3.

Back S (2020) SARS-CoV-2 envelope protein identified as target for antiviral drugs. Frontiers in Cellular and Infection Microbiology article. Scienceboard.net, The Science Advisory Board July 27, 2020.

Baker R, Yang W, Vecchi G, Metcalf C, Grenfell B (2020) Susceptible supply limits the role of climate in the early SARSCoV-2 pandemic. Science18 May 2020: eabc2535. doi:10.1126/science.abc2535.

Bashri G, Parihar P, Singh R, Singh S, Singh V, Prasad S (2016) Physiological and biochemical characterization of two Amaranthus species under $\mathrm{Cr}(\mathrm{VI})$ stress differing in $\mathrm{Cr}$ (VI) tolerance. Plant Physiology and Biochemistry 108: 12-23. https://doi.org/10.1016/j.plaphy.2016.06.030.

Baumi F, Narayani R, Sanders D, Patel V, Quizhpe A (2009) Social vaccines to resist and change unhealthy social and economic structures: a useful metaphor for health promotion. Health Promotion International 24(4): 428-433. doi:10.1093/heapro/dap026.

Beverly A (2020) Modeling coronavirus infection. Science 369 (6504) : 640.doi:10.1126/science.369.6504.640-b.

Bio Spectrum News (2020) Homeopathy in managing viral infections like COVID-19. $10 \quad$ April 2020.https://www.biospectrumindia.com/news/77/16194/homeopat hy-in-managing-viral-infections-like-covid-19.html.

Black S (2020) Biosimulation can mitigate risk of COVID-19 drug development.

Blumenthal D, Fowler EJ, Abrams M, Collins SR (2020) Covid-19 - Implications for the Health Care System. New England Journal of Medicine 383:1483-1488. doi: 10.1056/NEJMsb2021088.

Bonilla-Aldana DK, Dhama K, Rodriguez-Morales AJ (2020) Revisiting the One Health Approach in the Context of COVID-19: A look into the Ecology of this Emerging Disease. Advances in Animal and Veterinary Science 8(3): 234-237.

Bougrine R, Hdidou Y, Aissaoui H, Elouafi N, Ismaili N (2019) Emergency stay triggered Tako-Tsubo syndrome: A case report and review of the literature. Global Journal of Medical and Clinical Case Reports 6(2): 035-038. https://dx.doi.org/10.17352/24555282.000077 .

Boukar O, Belko N, Chamarthi S, et al. (2019) Cowpea (Vignaunguiculata): Genetics, genomics and breeding. Plant Breeding 138: 415-424. https://doi.org/10.1111/pbr.12589.
Brennan FR, Jones TD, Hamilton WDO (2001) Cowpea mosaic virus as a vaccine carrier of heterologous antigens. Molecular Biotechnology 17: 15-26. https://doi.org/10.1385/MB:17:1:15.

Brouwer PJM, Caniels TG, Straten KVD, Snitselaa JL, Aldon Y, et al.(2020) Potent neutralizing antibodies from COVID-19 patients define multiple targets of vulnerability. Science, First Release 15 Jun 2020: 1-14. doi: 10.1126/science.abc5902 (2-020).

Buschman E, Skamene E (2019) Genetic Resistance to Coronavirus Infection- A Review. Part of the Advances in Experimental Medicine and Biology book series (AEMB, volume 380), Springer Nature Switzerland AG. Part of Springer Nature. Corona- and Related Viruses 2019;1-11. https://www.springer.com/gp/book/9781461357759.

CABI (2020) Amaranthus viridis (Slender amaranth). CABI Data sheet, CAB International, Register EU trademark, Last update:10th Jan. 2020

Cal Y, Zhang J, Xiao T, Peng H, Sterling SM, Walsh Jr RM, Rawson S (2020) Distinct conformational states of SARS-CoV-2 spike protein. Science 21 Jul 2020:eabd4251. doi: 10.1126/science.abd4251.

Callif BL (2020) The Human Genome Is Full of Viruses. Medium, Medical Myths and Models. https://medium.com/medical-mythsand-models/the-human-genome-is-full-of-viruses-c18ba52ac195.

Capell T, Twyman R, Armario-Najera V, Ma J, Schillberg S, Christou P (2020) Potential Applications of Plant Biotechnology against SARS-CoV-2. Trends in Plant Science 25(7): 635-643. https://doi.org/10.1016/j.tplants.2020.04.009.

Casanova LM, Jeon S, Rutala WA, Weber DJ, Sobsey MD (2010) Effects of air temperature and relative humidity on coronavirus survival on surfaces. Applied and Environmental Microbiology 76(9):2712-2717.https ://doi.org/10.1128/aem.02291-09.

Centers for Disease Control and Prevention (CDC) (2020a) Food and coronavirus disease 2019 (COVID-19). https ://www.cdc.gov/coron aviru s/2019-ncov/daily -life-copin g/foodand-COVID-19.html.

Centers for Disease Control and Prevention (CDC) (2020b) Update:COVID-19 among workers in meat and poultry processing facilities-United States, April-May 2020. https ://www.cdc.gov/mmwr/volumes/69/wr/mm692 7e2.htm.

Centers for Disease Control and Prevention (CDC) (2020c) Cleaning and disinfecting. https ://www.cdc.gov/coron aviru s/2019-ncov/community/clean -disinfect/index .html. 
Ceyla Z, Meral R, Cetinkaya T (2020) Relevance of SARS-CoV-2 in food safety and food hygiene: potential preventive measures, suggestions and nanotechnological approaches. Indian Virological Society 2020, Virus Disease 31(2):154-160. https://doi.org/10.1007/s13337-020-00611-0.

CGTN (2020) Officials rule out domestic transmission as origin of Dalian COVID-19 cluster. https ://news.cgtn.com/news/2020-0803/Epidemic-in-Dalian-is-presumed-to-be-caused-byoverseasimports-SEiVRpdoEE /idex.html.

Chatterjee A, Sukul NC (1981) Total protein of galled roots as an index of root-knot nematode infestation of lady finger plants Phytopathology 71: 372-274.

Ciotti M, Ciccozzi M, Terrinoni A, Jiang WC, Wang CB, Bernardini S (2020) The COVID-19 pandemic. Critical Reviews in Clinical Labortatory Sciences 57(6):365-388.

Christie JR, Perry VG (1951) Removing nematodes from soil. Proceedings of the Helminthological Society of Washington18(2): 106-108.

https://www.cabdirect.org/cabdirect/abstract/19510801392.

Cohen J (2020a) Controversial 'human challenge' trials for COVID-19 vaccines gain support. Science, ScienceMag.org,Science's COVID-19 reporting is supported by the Pulitzer Center and the Heising-Simons Foundation, Posted in: HealthCoronavirusJul.20, 2020. doi:10.1126/science.abd9203.

Cohen J (2020b) United States should allow volunteers to be infected with coronavirus to test vaccines, lawmakers argue. Science, Posted in: Health Science and Policy Coronavirus. Apr. 21, 2020. doi:10.1126/science.abc3772.

Cohen J (2020c) Designer antibodies could battle COVID-19 before vaccines arrive. Science Aug. 4, 2020.Posted in: Health Coronavirus. doi:10.1126/science.abe 1740 .

Corey L, Mascola JR, Fauci AS, Collins FS (2020) A strategic approach to COVID-19 vaccine R\&D. Published online 11 May 2020 Science. doi: 10.1126/science.abc5312.

http://science.sciencemag.org/content/early/2020/05/12/science.abc5312.

Crop Biotech Update (2020a) A Call to Action for World Leaders: Prevent Global Food Security Crisisin COVID-19 Fight.http://www.isaaa.org/kc/cropbiotechupdate/article/default.as $\mathrm{p} ? \mathrm{ID}=18079$.

Crop Biotech Update (2020b) Viable Vaccine Candidate for COVID-19 Developed Using ProprietaryPlant-based Technology. http://www.isaaa.org/kc/cropbiotechupdate/article/default.asp?ID= 18028.
Datta SC, Sinhababu SP, Sukul NC (1997) Improved growth of silkworms from effective treatment of mulberry diseases by Acacia auriculiformis extract. Sericologia 37: 707-715.

Datta SC, Sinhababu SP, Banerjee N, Ghosh K, Sukul NC (1998) Melodogyne incognita extract reduces Melodogyne incognita infestation in tomato. Indian Journal of Nematology 28: 1-5.

Datta SC (1999) Bio-nematicides in the control of root-knot nematode.Ph.D. thesis, Department of Zoology, VisvaBharati, Santiniketan-731235, West Bengal, India(unpublished).

Datta SC, Datta R (2000) Defence resistance of okra against rootknot disease by bio-nematicides. Proceedings of the Zoological Society, Calcuutta University, Calcutta, West Bengal 59(2): 75-82.

Datta SC, Datta R, Suku, A, Sukul NC, Sinhababu SP (2000) Relative attractiveness of four species of vegetable crops for Meloidogyne incognita. Environment and Ecology 18: 233-235.

Datta SC (2005) Plant parasitic nematodes - an agricultural problem and its solutions. The Visva Bharati Quarterly 11: 89-100.

Datta SC (2006) Effects of Cinaon root-knot disease of mulberry. Homeopathy 95: 98-102.

Datta SC, Datta R (2012) Homeopathic Medicines Protect Environment, Health and Development by Controlling Mulberry Diseases. Journal of Traditional Medicine \& Clinical Naturopathy 1: $104 . \quad$ https://www.omicsonline.org/open-access/2167206.1000104.php?

Datta SC, Datta R (2013) Efficacy of homeopathic medicineAakashmoni as potential bio-agent against various plant pathogens. Journal of Biochemistry \& Pharmacology 2: 4. http://dx.doi.org/10.4172/2167-0501.S1.004.

Datta SC, Das R, Chatterjee K, Mondal B, Das R (2016) Amaranth Plant: Protects Climate, Health and Development by Controlling Root-Knot Disease. Journal of Environmental \& Analytical Toxicology 6: 341. doi:10.4172/2161-0525.1000341.

Datta SC, Datta R (2016) Prevention and control of root-knot disease of mulberry plants using bioagents amaranth plants: improving sericulture by protecting climate health, health and development. Journal of Environment \& Sociobiology 13: $191-200$.

Datta SC (2019a) Improved Environment by Identification of More Susceptible Plant Between Cowpea and Mulberry for Root-Knot Disease. Open Access Journal of Environmental Soil Science 2(5): 242-245. doi:10.32474/OAJESS.2019.02.000148. 
Datta SC (2019b) Enriched Sericulture from Effective Treatmen of Mulberry Diseases by Homeopathic Medicines. Advances Biochemistry Biotechnology 17: 084. doi:10.29011/25747258.000084

Datta SC (2020a) Enriched Science and Technology Communication Economy in Agriculture by Use of Acacia sides as Potential Bio-Agents against Various Pathogens.Advances in Agriculture, Horticulture and Entomology 2: 1-13.

Datta SC (2020b) Discovery of COVID-19 Vaccine by Using Acaciades as a Phytomedicine Improving Science and Technology Communication Applications- An Ideas. Open Access Journal of Biogeneric Science and Research 2(1): 1-30. doi:10.46718/JBGSR.2020.01.000032.

Datta SC (2020c) Improved Science and Technology Communications: Barn Owl Act As Social Vaccine Against COVID-19. International Journal of Latest Research in Science and Technology 9(3): 6-13 https://www.mnkjournals.com/journal/ijlrst/Article.php?paper_id= 10994.

Datta SC (2020d) Okra Maybe Potential Cost-Effective Personalized-Biomedicines Social-Vaccine against COVID-19: Improved Immunity Food-Security Green-Economy Science-andTechnology-Communication Applications. Innovative Journal of Medical Sciences 4(2): 5-20.

Datta SC (2020e) Potential Policy-Developed Global-COVID-19Vaccine: Enriched Medical Sciences and Technology GreenSocio-Economy. Cross Current International Journal of Medical $\begin{array}{lll}\text { and } \quad \text { Biosciences } & \text { 2(10): }\end{array}$ doi:10.36344/ccijmb.2020.v02i10.001.

Datta SC (2020f) Intercropped Cowpea Maybe Use as Biomedicine Improved Immunity against COVID-19: Enriching Science and Technology Communication Applications Food Security Economy. Diagnosis and Therapies: Complementary and Traditional Medicine (Early Online In Progress).https://ospopac.com/journals/All.

Datta SC (2020g) Improved midday meal by using cowpea as ecofriendly crop controlling root-knot forming global, green, growth and green economy. International Journal of Advanced Research. (Accepted)

Datta SC (2020h) Biomedicines-Cina against COVID-19: Controlled Plant Diseases Enriched Science and Technology Communication Green Economy. The International Journal of Research -GRANTHAALAYAH 8(9): 234-255. https://doi.org/10.29121/granthaalayah.v8.i9.2020.1537.
Devanssh (2020) Possible Plant Based Medicines And Phytochemicals To Be Cure For Deadly Coronavirus COVID 19. World Journal Of Pharmacy And Pharmaceutical Sciences. 9. 531533 .

Devi CB, Kushwaha A, Kumar A (2015) Sprouting characteristics and associated changes in nutritional composition of cowpea (Vignaunguiculata). Journal of Food Science and Technology 52: $6821-6827$.

Dhama K, Wani MY, Deb R, Karthik K, Tiwari R, Barathidasan R, Kumar A, Mahima, Verma AK, Singh SD (2013). Plant based oral vaccines for human and animal pathogens - a new era of prophylaxis: Current and future perspectives. Journal of Experimental Biology and Agricultural Sciences 1(1): 1-12.

Dhama K, Saminathan M, Jacob SS, Singh M, Karthik K, Amarpal, Tiwari R, Sunkara LT, Malik YS, Singh RK (2015) Effect of immunomodulation and immunomodulatory agents on health with some bioactive principles, modes of action and potent biomedical applications. International Journal of Pharmacology 11(4): 253-290

Dhama K, Karthik K, Khandia R, Munjal A, Tiwari R, Rana R, Khurana SK, Sana Ullah, Khan RU, Alagawany M, Farag MR, Dadar M, Joshi SK. (2018) Medicinal and therapeutic potential of herbs and plant metabolites / extracts countering viral pathogens Current knowledge and future prospects. Current Drug Metabolism 19(3):236-263.

Dhama K, Khan S, Tiwari R, Sircar S, Bhat S, Malik YS, Singh KP, Chaicumpa W, Bonilla-Aldana DK, Rodriguez-Morales AJ (2020a) Coronavirus Disease 2019-COVID-19. Clinical Microbiology Reviews 33(4):e00028-20. doi: 10.1128/CMR.00028-20.

Dhama K, Natesan S, Yatoo MI, Patel SK, Tiwari R, Saxena SK, Harapan H (2020b) Plant-based vaccines and antibodies to combat COVID-19: Current status and prospects. Human Vaccines and Immunotherapeutics. $16(12)$ : https://doi.org/10.1080/21645515.2020.1842034

Divya M, Vijayakumar S, Chen J, Vaseeharan B, Durán-Lara EF (2020) A review of South Indian medicinal plant has the ability to combat against deadly viruses along with COVID-19?. Microbial Pathogenesis. https://doi.org/10.1016/j.micpath.2020.104277

Drug Target Review (2020) COVID-19 research hub, 2020. https://www.drugtargetreview.com/research_hub/covid-19/.

Editorials (2020) Covid-19: Managing the Surge. Innovations in Care Delivery, NEJM Catalyst Collection, 22 ${ }^{\text {nd }}$ July2020: 1-97. 
Fabbri ADT, Crosby GA (2016) A review of the impact of preparation and cooking on the nutritional quality of vegetables and legumes. International Journal of Gastronomy and Food Science 3: 2-11.https://doi.org/10.1016/j.ijgfs.2015.11.001

Food and Drug Administration (FDA) (2020a) Enforcement Policy for Sterilizers, Disinfectant Devices, and Air Purifiers During the Coronavirus Disease 2019 (COVID-19) Public Health Emergency. Guidance for Industry and Food and Drug Administration Staff March 2020. U.S. Department of Health and Human Services Food and Drug Administration Center for Devices and Radiological Health.

Food and Drug Administration (FDA) (2020b) Food safety and the $\begin{array}{lll}\text { coronavirus } & \text { disease } & 2019 \quad \text { (COVID-19).https }\end{array}$ ://www.fda.gov/food/food-safet y-during-emergencies/food-safetyand-coronavirus-disease-2019-covid-19.

Food Standards Scotland (FSS) (2020) Coronavirus (COVID-19) and food, coronavirus questions and answers.https ://www.foodstandards.gov.scot/consumers/food-safet y/coronavirus/quest ions-and answers-covid-19.

Food and Agriculture Organization of the United Nations [FAO] and World Health Organization [WHO] (2020).COVID-19, And Food Safety.Guidance for Food Businesses. Interim Guidance, April, 1-6. Geneva: WHO.

Filetti S (2020) The COVID-19 pandemic requires a unified global response. Springer Science Business Media, LLC, part of Springer Nature, Endocrine 2020; 68: 1(2020) https://doi.org/10.1007/s12020-020-02293-6.

Firenzuoli F, Antonelli M, Donelli D, Gensini GF, Maggini F (2020) Cautions and Opportunities for Botanicals in COVID-19 Patients: A Comment on the Position of the French Agency for Food, Environmental and Occupational Health \& Safety. The Journal of Alternative and Complementary Medicine 26(10): 1-3. doi: 10.1089/acm.2020.0266.

Fobar R (2020) China promotes bear bile as coronavirus treatment, alarming wildlife advocates. National Geographic, Animals Coronavirus Coverage, Published March 25, 2020. (C) 1996-2015 National Geographic Society, (C) 2015- 2020 National Geographic Partners, LLC. All rights reserved.https://www.nationalgeographic.com/animals/2020/03/Ch inese-government-promotes-bear-bile-as-coronaviruscovid19treatment.html

Gemede HF, Ratta N, Haki GD, Woldegiorgis AZ, Beyene F (2015) Nutritional Quality and Health Benefits of Okra (Abelmoschus esculentus): A Review. Journal of Food Processing \& Technology 2015:6: 458. doi:10.4172/2157-7110.1000458.
Gibbons A (2020) Ancient microbial arms race sharpened our immune system - but also left us vulnerable. Science, ScienceMag.Org. Jul. 24, 2020.

Gómez DM, Lone YC, Salazar LM, Trojan J (2019) Antimicrobial peptides, novel solution for the treatment of precancerous disease acne - A review. Trends in Medicine 19: 1-6.

Gondwe TM, Alamu EO, Mdziniso P, Maziya-Dixon B (2019) Cowpea (Vigna unguiculata (L.)Walp) for food security: an evaluation of end-user traits of improved varieties in Swaziland. Scientific Reports 9: 15991. https://doi.org/10.1038/s41598-01952360-w.

Govender N (2020) Amaranth - an Aid to Eating and Staying Healthy during COVID-19.News, Science and Indigenous Knowledge Education in UKZN's School of Education.https://soe.ukzn.ac.za/news/2020/05/amaranth-an-aidto-eating-and-staying-healthy-during-covid-19/.

Gorski D (2020) Chinese medicine's use of animals a threat to entire world. WILDLIFE \& BIODIVERSITY, Published: Tuesday 07 April 2020. https://www.downtoearth.org.in/wildlife-andbiodiversity.

Guleria R, Srivastava DN (2020) COVID-19: A Global Health Concern. Annals of the National Academy of Medical Sciences (India) 56(02): 053-054. doi:10.1055/s-0040-1713959.

Hammett E (2020) How long does Coronavirus survive on different surfaces? $\quad$ BDJ Team 7(5): 1415.https://doi.org/10.1038/s41407-020-0313-1.

Han J, Zhang X, He S, Jia P (2020) Can the coronavirus disease be transmitted from food? A review of evidence, risks, policies and knowledge gaps. Environmental Chemistry Letters. (C) Springer Nature Switzerland AG 2020; 1-12. https://doi.org/10.1007/s10311-020-01101-x.

Hema M, Vardhan GPV, Savithri HS, Murthy MRN (2019)Chapter 6: Emerging Trends in the Development of Plant Virus-Based Nanoparticles and Their Biomedical Applications. Recent Developments in Applied Microbiology and Biochemistry 2019: 6182. https://doi.org/10.1016/B978-0-12-816328-3.00006-4.

Hessling M, Hoenes K, Lingenfelder C (2020) Selection of parameters for thermal coronavirus inactivation - a data-based recommendation. GMS Hygiene and Infection Control 13;15:Doc16. doi: 10.3205/dgkh000351.

Hoffmann M, Kleine-Weber H, Schroeder S, et al. (2020) SARSCoV2 cell entry depends on ACE2 and TMPRSS2 and is blocked by a clinically proven protease inhibitor. Cell 181(2): 271-280. 
ISAAA Shares (2020) Pocket K No. 58: COVID-19 Treatment Efforts Using Plant Technologies. http://www.isaaa.org/resources/publications/pocketk/58/default.asp.

IUCN (1993) The International Union for Conservation of Nature and Natural Resources, World Health Organization and World Wide Fund for Nature. Guidelines on the conservation of medicinal plants. Gland, Switzerland.

Jahan I, Onay A (2020) Potentials of plant-based substance to inhabit and probable cure for the COVID-19. Turkish Journal of Biology 44(3):228-241.

Jayathilake C, Visvanathan R, Deen A, Bangamuwage R, Jayawardana BC, Nammic S, Liyanagea R (2018) Cowpea: an overview on its nutritional facts and health benefits. Journal of the Science of Food and Agriculture. DOI 10.1002/jsfa.9074.

John AJ, Julie RI, Beth HM, D'Agostino BR, Harrington PD (2020) Inhibitors of the Renin-Angiotensin-Aldosterone System and Covid-19. The new England Journal of Medicine. 382:24622464. DOI: 10.1056/NEJMe2012924.

Julka A (2020) Coronavirus India News Live Updates 24 April 2020: COVID-19 Cases Soar Past 24000. Grain Mart India News, April 24, 2020. https://www.grainmart.in/news/coronavirus-indianews-live-updates-24-april-2020-covid-19-cases-soar-past-23000/.

Kaiser J (2020) To streamline coronavirus vaccine and drug efforts, NIH and firms join. Science $17^{\text {th }}$ April 2020: Health Scientific Community Coronavirus. doi:10.1126/science.abc3180

Karamchandani A, Rathi S (2020) Government With CSR Funds Going to COVID-19, NGOs Are Looking at Steep Reduction in Corporate Support. The WIRE 09/MAY/2020. https://thewire.in/government/csr-covid-19-ngos.

Kochlar SI (1986) Okra (lady finger) in tropical crops, a text book of economic botany 1: 263-264.

Kumaraswamy L (2016) Cucumber-A Natural Medicine and its Therapeutic Potentia.RPMP Phytotherapeutics 43: 1-8. https://www.academia.edu/11681662/Cucumber_A_Natural_Medi cine_and_its_Therapeutic_Potentia.

Kuete V, Karaosmanoğlu O, Sivas H (2017) Anticancer Activities of African Medicinal Spices and Vegetables. Medicinal Spices and Vegetables from Africa Therapeutic Potential Against Metabolic, Inflammatory, Infectious and Systemic Diseases, https://doi.org/10.1016/B978-0-12-809286-6.00010-8.

Kupferschmidt K (2020) Vaccine nationalism' threatens global plan to distribute COVID-19 shots fairly. Science, ScienceMag.Org. Jul. 28, 2020.
Lanham-New SA, Webb AR, Cashman KD, et al.(2020) Vitamin D and SARS-CoV-2 virus/COVID-19 disease. BMJ Nutrition, Prevention \& Health 2020,May 13. doi:10.1136/bmjnph-2020000089

Leslie M (2020) T cells found in COVID-19 patients 'bode well' for long-term immunity. Science's COVID-19 reporting is supported by the Pulitzer Center Science, Science Mag Org,May'14, 2020. Available from:doi:10.1126/science.abc8120.

Lowry OH, Rosebrough NJ, Farr AL, Randall RJ (1951) Protein measurement with the Folin-Phenol reagent. Journal of Biological Chemistry 93: 265-275.

Madhusoodanan J (2020) Ethically troubling.' University reopening plans put professors, students on edge. Science, ScienceMag.org,Jul. 20， 2020. Posted in: CoronavirusCareerrelated PolicyNon-disciplinary. doi:10.1126/science.caredit.abd9178

Martin Y (2020) Oxford COVID-19 vaccine shows real promise. NEWSLETTER, Medical News Today, July 21, 2020 - Fact checked by Isabel Godfrey. https://www.medicalnewstoday.com/articles/oxford-covid-19vaccine-shows-real-promise.

Massawe PI, Mtei KM, Munishi LK, Ndakidemi PA (2016). Existing practices for soil fertility management through cerealslegume intercropping systems Nigeria. World Research Journal of Agricultural Sciences 3(2): 080-091.

Malik YS, Kumar N, Sircar S, Kaushik R, Bhat S, Dhama K, Gupta P, Goyal K, Singh MP, Ghoshal U, El Zowalaty ME, O R V, Yatoo MI, Tiwari R, Pathak M, Patel SK, Sah R, RodriguezMorales AJ, Ganesh B, Kumar P, Singh RK (2020) Coronavirus Disease Pandemic (COVID-19): Challenges and a Global Perspective. Pathogens 9(7):519.

Mani J, Johnson J, Steel J, Broszczak D, Neilsen P, Walsh K, Naiker M (2020) Natural product-derived phytochemicals as potential agents against coronaviruses: A review. Virus Research 2020(284):197989.doi:10.1016/j.virusres.2020.197989

Moe $\mathrm{T}$ (1998) Perspectives on traceability in food manufacture. Trends in Food Science \& Technology 9(5): 211-214.

NDTV FOOD (2020) 9-Best Amaranth Recipes For Healthy Lifestyle Easy Rajgira Recipes. https://food.ndtv.com/fooddrinks/8-best-amaranth-recipes-for-healthy-lifestyle-1850899.

Nicks, Bret A, Wong O (2020) Coronavirus Disease 2019 (COVID19): A Global Crisis. https://reference.medscape.com/slideshow/2019novel-coronavirus-6012559. 
NIH (2017) Clinical Alerts and Advisories /Disclaimer.U.S. National Library of Medicine, ClinicalTrials.gov. This page last reviewed in September 2017. https://www.nih.gov/coronavirus and https://www.coronavirus.gov.

Olaimat AN, Shahbaz HM, Fatima N, Munir S, Holley RA (2020) Food Safety During and After the Era of COVID-19 Pandemic. Frontiers in Microbiology 11:1854.doi:10.3389/fmicb.2020.01854.

Olowolaju ED, Okunlola GO (2017) Comparative advantage of intercropping maize, cowpea and tomato to sole and mixed culture. Annals of West University of Timişoara, SerBiol20(1): 31-38

Olsen P, Borit M (2013) How to define traceability. Trends in Food Science \& Technology 29(2): 142-150.

On Biology (2019) The viral content of human genomes is more variable than we thought. Rebecca Pearce. Journal Development Manager at BMC, 25 Jan 2019, Blog Network.

Panyod S, Ho CT, Sheen LY (2020) Dietary therapy and herbal medicine for COVID-19 prevention: A review and perspective. Journal of Traditional and Complementary Medicine 10(4):420427.

Parvathy S (2020) Engineering Plants as Platforms for Production of Vaccines. American Journal of Plant Sciences11: 707-735. https://doi.org/10.4236/ajps.2020.115052.

Pulipati S, Babu P, Narasu M (2014) Phytochemical and pharmacological potential of Amaranthus viridis L. International Journal of Phytomedicine 6(3): 322-326.

Rabaan AA, Al-Ahmed SH, Sah R, Tiwari R, Yatoo MI, Patel SK, Pathak M, Malik YS, Dhama K, Singh KP, Bonilla-Aldana DK, Haque S, Martinez-Pulgarin DF, Rodriguez-Morales AJ, Leblebicioglu H. (2020) SARS-CoV-2/COVID-19 and advances in developing potential therapeutics and vaccines to counter this emerging pandemic. Annals of Clinical Microbiology and Antimicrobials 19(1):40. doi: 10.1186/s12941-020-00384-w.

Rahal A, Mahima, Verma AK, Kumar A, Tiwari R, Kapoor S, Chakraborty S, Dhama K (2014) Phytonutrients and nutraceuticals in vegetables and their multi-dimensional medicinal and health benefits for humans and their companion animals: A review. Journal of Biological Science 14(1): 1-19.

Rajput H (2012) Homeopathic Prophylaxis: Just Homeopathic Vaccination or More. Journal of Homeopathy \& Ayurvedic Medicine 1: 105. doi:10.4172/2167-1206.1000e105.

Raw I (2020) Butantan Institute: From Snakes to Vaccines and its Destruction. Internal Medicine Review 6(3): 1-14.
Robert F (2020) AI invents new 'recipes' for potential COVID-19 drugs. Science, Posted in: HealthTechnologyCoronavirus. doi:10.1126/science.abe2266.

Rodriguez-Morales AJ, Bonilla-Aldana DK, Tiwari R, Sah R, Rabaan AA, Dhama K (2020) COVID-19, an emerging coronavirus infection: current scenario and recent developments an overview. Journal of Pure and Applied Microbiology 14(1): 0512. https://doi.org/10.22207/JPAM.14.1.02

Roossinck MJ (2001) Pathogen profile Cucumber mosaic virus, a model for RNA virus evolution. Molecular Plant Pathology 2(2): $59-63$.

Roujian L, Xiang Z, Juan L, Peihua N, Bo Y, Honglong W, et al. (2020) Genomic characterisation and epidemiology of 2019 novel coronavirus: implications for virus origins and receptor binding. The Lancet, 395(10224): 565-574.doi: 10.1016/S01406736(20)30251-8.

Science Daily (2016)Our complicated relationship with viruses. Science News, November 28, 2016 NIH, National Institute of General Medical Sciences (NIGMS). www.sciencedaily.com/releases/2016/11/161128151050.htm.

Science Daily (2020) The genetic quest to understand COVID-19: Unlocking the genetic code of the novel coronavirus will help us prevent other diseases. Science Daily, Science News, 26 March 2020, University of Sydney.https://www.sciencedaily.com/releases/2020/03/20032614 4357.htm.

Shah F, Wu W (2019)Soil and Crop Management Strategies to Ensure Higher Crop Productivity within Sustainable Environments. Sustainability 11: 1485. doi:10.3390/su11051485.

Shariatifar N, Molaee-Aghaee E (2019) A novel coronavirus 2019 (COVID-19): important tips on food safety. Journal of Food Safety and Hygiene 5: 58-59. doi:10.18502/jfsh.v5i1.3886.

Shrock E, Fujimura E, Kula T,Timms RT, Lee IH, Leng Y (2020)Viral epitope profiling of COVID-19 patients reveals crossreactivity and correlates of severity. Science. First Release : 29 September 2020:1-23. 10.1126/science.abd4250 (2020). http://science.sciencemag.org/content/early/2020/09/28/science.ab d4250.

Sindhu RK, Puri V (2016) Phytochemical, Nutritional and Pharmacological evidences for Abelmoschusesculentus (L.). The Journal of Phytopharmacology 5(6): 238-241.

Soler MJ, Barrios C, Oliva R, Batlle D (2008) Pharmacologic modulation of ACE2 expression. Current Hypertension 10: 410-4. 
Shenzhen Municipal Health Commission (SMHC) (2020) Detection of SARS-CoV-2 on an imported chicken wing sample.From: Shenzhen Epidemic Prevention and Control Headquarters, Updated: 2020-08-13 17:08. http://www.sz.gov.cn/en_szgov/news/notices/content/post_800028 5.html.

Staff Reporter (2020) Corona Vaccine will be prepared from the extract of fruits of Aakashmoni plants- Opinion of the researcher of Burdwan. Agnirath News, Reg.No.WBBEN/2000/2086,Burdwan, $15^{\text {th }}$ April 2020, 21(8): 1-3.

Standaert M (2020) This makes Chinese medicine look bad': TCM supporters condemn illegal wildlife trade. The Guardian, Tue 26 May 2020 07.30 BST.

GOI (2020a) As India and the world reorient in the wake of the COVID-19 crisis, a landmark policy initiative has been flagged by the Government of India. The Science, Technology and Innovation Policy, 2020 (STIP2020). https://www.mygov.in/campaigns/stip$2020 /$.

GOI (2020b) Government of India is taking all necessary steps to ensure that we are prepared well to face the challenge and threat posed by the growing pandemic of COVID 19 - the Corona Virus.https://www.mygov.in/campaigns/.

https://www.mygov.in/task/covid-19-solution-challenge/.

Sukul NC (1987) Soil and plant nematodes. West Bengal State Book Board Publication Calcutta 1987: 1-271

Sweeney C (2020) Human Immunomics Initiative will decode immune system, speed new vaccines. Harvard T.H. Chan School of Public Health News, April 14, 2020, Copyright (C) 2020 The President and Fellows of Harvard College csweeney@hsph.harvard.edu,

617.549.2638.https://www.hsph.harvard.edu.

The Gene (2020)The COVID-19 Disease and Our Genes. Ken Burns,A special post from guest writer Joshua SpeiserApril 7, 2020.

Thomas W, Burke I, Spears J, Wilcut J (2009) Influence of environmental factors on slender amaranth (Amaranthusviridis) germination. Weed Science. doi:10.1043/00431745(2006)54[316:IOEFOS]2.0.CO;2

Thorp H (2020) A dangerous rush for vaccines.Editor-in-Chief, Science journals. hthorp@aaas.org; @hholdenthorp, Science, published online August 13, 2020, 10.1126/science.abe3147(2020).

http://science.sciencemag.org/content/early/2020/08/12/science .abe3147.
Tiwari R, Latheef SK, Ahmed I, Iqbal H, Bule MH, Dhama K, Samad HA, Karthik K, Alagawany M, El-Hack ME, Yatoo MI, Farag MR (2018) Herbal Immunomodulators - A Remedial Panacea for Designing and Developing Effective Drugs and Medicines: Current Scenario and Future Prospects. Current Drug Metabolism 19(3): 264-301.

Tiwari R, Dhama K, Sharun K, Iqbal Yatoo M, Malik YS, Singh R, Michalak I, Sah R, Bonilla-Aldana DK, Rodriguez-Morales AJ (2020) COVID-19: animals, veterinary and zoonotic links. Veterinary Quarterly 40(1):169-182. doi: 10.1080/01652176.2020.1766725.

Ul Q, Alqahtani S, Alamri M, Chen L (2020) Structural Basis of SARS-CoV-2 3CLpro and Anti-COVID-19 Drug Discovery from Medicinal Plants. Journal of Pharmaceutical Analysis. https://www.sciencedirect.com/science/article/pii/S209517792030 1271\#!

Unhale SS, Ansar QB, Gajghane V, BharudkarSS, Gadekar PP, Biyani KR (2020) Impact of COVID-19 on Food Safety and Food Security. World Journal of Advanced Healthcare Research 4: 126-129.

Valipour M (2014) Handbook of water engineering problems. Foster City (CA): OMICS Group eBooks 2014. http://www.esciencecentral.org/ebooks/handbook-of-waterengineering-problems/pdf/handbook-of-water-engineeringproblems.pdf.

Valipour M (2015) What is the tendency to cultivate plants for designing cropping intensity in irrigated area? Advance in Water Science and Technology 2015: 01-12.

Vyawahare M (2020) Illegal pangolin trade may have played a part in coronavirus outbreak. News Mongabay.Article published by malavikavyawahareon $\quad 13 \quad$ February 2020. https://form.jotform.com/91615182854158.

Ware M (2019) Benefits and uses of okra.MEDICAL NEWS TODAY NEWSLETTER. November 6, 2019. https://www.medicalnewstoday.com/articles/311977

Wee SL (2020) In Coronavirus, China Weighs Benefits of Buffalo Horn and Other Remedies.

Werner K, Werner K, Risko N, Burkholder T, Munge K, et al. (2020) Cost-effectiveness of emergency care interventions in low and middle income countries: a systematic review.Bull World Health Organ 98: 341-352.Doi: http://dx.doi.org/10.2471/BLT.19.241158.

Williams SCP (2015) Humans may harbor more than 100 genes from other organisms. Science, Mar.12, 2015, Posted in: Biology. doi:10.1126/science.aab0307. 
WHO (2015) Plant-derived Vaccines. Available at https://www.who.int/biologicals/vaccines/plant_derived_vaccines/ en/ access on $25^{\text {th }}$ August 2020 .

WHO (2020a) Coronavirus disease (COVID-2019) An international randomized trial of candidate vaccines against COVID-19 version.World Health Organization's, R\&D Blueprint 19 April 2020. https://www.who.int/teams/blueprint/covid-19.

WHO (2020b) A Global Collaboration to Accelerate the Development, Production and Equitable Access to New COVID19 diagnostics, therapeutics and vaccines. Available at https://www.who.int/news-room/detail/24-04-2020-commitmentand-call-to-action-global-collaboration-to-accelerate-new-covid19-health-technologies, access on $25^{\text {th }}$ August 2020.

World Health Organization (2020c) WHO supports scientificallyproven traditional medicine. WHO Africa, Brazzaville 04 May 2020.

WHO (2020d) Vaccine-preventable diseases and vaccines.International travel and health. Chapter 6: 1-61, See country list updated yearly on WHO's ITH web page at: http://www.who.int /ith/en/ http://www.who.int/immunization standards/vaccine_quality/PQ_vaccine_list_en/en/

WHO (2020) WHO Timeline -COVID-19 https://www.who.int/news-room/detail/27-04-2020-who-timeline--covid-19.

WHO (2020f) Coronavirus Disease (COVID-19) Dashboard. https://covid19.who.int/.

WHO (2020g) Coronavirus disease (COVID-19) advice for the public.Last updated 4 June 2020.https://www.who.int/campaigns/connecting-the-world-tocombat-coronavirus/healthyathome/healthyathome---healthy-diet.

World Health Organization (WHO) (2020h) COVID-19 and food safety: guidance for competent authorities responsible for national food safety control systems: interim guidance, 22 April 2020. https ://apps.who.int/iris/handl e/10665/33184 2.

World Health Organization (WHO) (2020i). COVID-19 and food safety: guidance for food businesses: interim guidance. World Health Organization.
World Health Organization (WHO) (2020j).Coronavirus Disease (COVID-19) Pandemic. Geneva: WHO. European Food Safety Authority [EFSA] (2020). Coronavirus: No Evidence That Food Is A Source Or Transmission Route. Parma: EFSA.

WHO-FAO (2020) COVID-19 and food safety: guidance for food businesses. Interim guidance; April 2020: 1-6.https : //apps.who.int/iris/bitstream/handl e/10665/33170 5/WHO-2019nCoV-Food_Safet y-2020.1-eng.pdf..

Xiang Y, Song Q, Gu W. (2020) Decontamination of surgical face masks and N95 respirators by dry heat pasteurization for one hour at $70^{\circ} \mathrm{C}$. American Journal of Infection Control 48(8):880-882. doi: 10.1016/j.ajic.2020.05.026.

XieX, Huang L, Li JJ, Zhu H (2020) Generational Differences in Perceptions of FoodHealth/Risk and Attitudes toward Organic Food and Game Meat: The Case of the COVID-19 Crisis in China. International Journal of Environmental Research and Public Health 30;17(9):3148. doi:10.3390/ijerph17093148.

Yang Y, Islam MS, Wang J, Li Y, Chen X (2020) Traditional Chinese Medicine in the Treatment of Patients Infected with 2019New Coronavirus (SARS-CoV-2): A Review and Perspective. International Journal of Biological Sciences 16(10): 1708-1717. doi:10.7150/ijbs. 45538

Yatoo MI, Hamid Z, Parray OR, Wani AH, Ul Haq A, Saxena A, Patel SK, Pathak M, Tiwari R, Malik YS, Sah R, Rabaan AA, Rodriguez Morales AJ, Dhama K. (2020) COVID-19 - Recent advancements in identifying novel vaccine candidates and current status of upcoming SARS-CoV-2 vaccines. Human Vaccines and Immunotherapeutics 16(12): 1-14. doi: $10.1080 / 21645515.2020 .1788310$.

Zhang YZ, Holmes EC (2020) A Genomic Perspective on the Origin and Emergence of SARS-CoV-2. Cell181 (2): 223227.doi:10.1016/j.cell.2020.03.035.

Zhang LK, et al. (2020) Structure-based design of antiviral drug candidates targeting the SARS-CoV-2 main protease. Cite as: W. Dai et al., Science10.1126/science.abb4489. http://science.sciencemag.org/content/early/2020/04/21/science.ab b4489. 